\title{
Activity Reason Code
}

National Cancer Institute

\section{Source}

National Cancer Institute. Activity Reason Code. NCI Thesaurus. Code C93705.

A coded value specifying the motivation, cause, or rationale of an activity. 